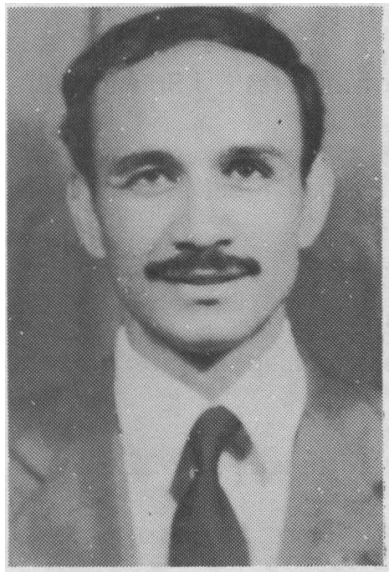

A. M. Elnashar

\section{PHYSICAL FITNESS STATUS OF EGYPTIAN CHILDREN AGED 9-18 YEARS}

\author{
A. M. ELNASHAR, MA* and J. L. MAYHEW, PhD
}

Human Performance Laboratory, Northeast Missouri State University, Kirksville, Missouri 63501, USA

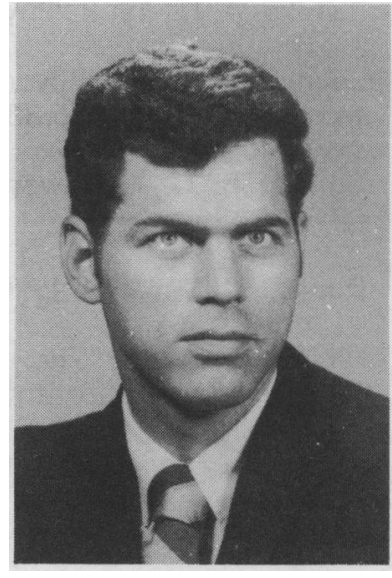

J. L. Mayhew

\title{
ABSTRACT
}

Male ( $n=399$ ) and female $(n=311$ ) Egyptian school children, aged 9-18 yrs, had their fitness evaluated using the 6-item AAHPER test. Comparisons of the 50th percentiles of the AAHPER norms with the median scores for the Egyptian sample revealed that the latter were substantially below average fitness levels. Egyptian boys performed significantly better than girls on all comparable test items, even when the effects of age, height, and weight were held constant by covariance. Eight weeks of twice weekly intensified physical education instruction produced significant improvements in all test items for both sexes.

Key Words: Fitness, AAHPER test, Muscular fitness, Comparative physical education.

Since the turn of the century there has been an unprecedented acceleration in industrialisation. Although the greatest influence of this advanced technological boom has been registered in Western Europe, the United States, and Japan, many emerging third-world countries, such as Egypt, have experienced the effect of increased mechanisation.

Instruments of modern technology have reduced the number of hours during the day which were devoted to maintaining an existence, leaving increased amounts of leisure time. Rather than pursue vigorous leisure-time activities, the majority chose to become more sedentary, often to the detriment of their health (Morris et al, 1953; Brunner and Manelis, 1960; Costas et al, 1978). In addition to the increase the hypokinetic diseases in highly industrialised nations, the Krause-Weber report (Krause and Hirschland, 1954) pointed out the superior fitness levels of Western Europeans over Americans. A renewed emphasis on fitness in the United States helped produce the AAHPER six-item fitness test (Hunsicker, 1957).

The AAHPER test has been used extensively in the

\section{"Present address:}

School of Physical Education,

University of Pittsburgh,

Pittsburgh, PA.
United States providing a data base from which to derive norms. Furthermore, numerous cross-cultural comparative studies have used the test to assess fitness (e.g., Campbell and Pohndorf, 1961; Knuttgen, 1961; Sloan, 1966). Generally, these reports revealed that foreign youth were superior to Americans on most test items. To date, however, there is little information on the fitness status of emerging third-world nations such as Egypt. Thus, the purposes of this study were to (1) compare fitness scores of Egyptian children with AAHPER norms, (2) compare fitness between Egyptian males and females, and (3) evaluate the effects of an intensive eight-week physical education programme on fitness scores.

\section{Methods}

The subjects for this study were 710 Egyptian males and females, aged 9-18 years, enrolled in physical education classes at 15 schools in Fayoum, Egypt, during the 1980-81 school year. All subjects were Egyptian citizens. Table I details the sample subdivisions and physical characteristics.

An 11-person committee administered all tests according to the AAHPER manual (AAHPER, 1976). Only two items were tested each week over a four-week period. Comparisons with AAHPER norms and between boys and girls were based on these initial tests. 

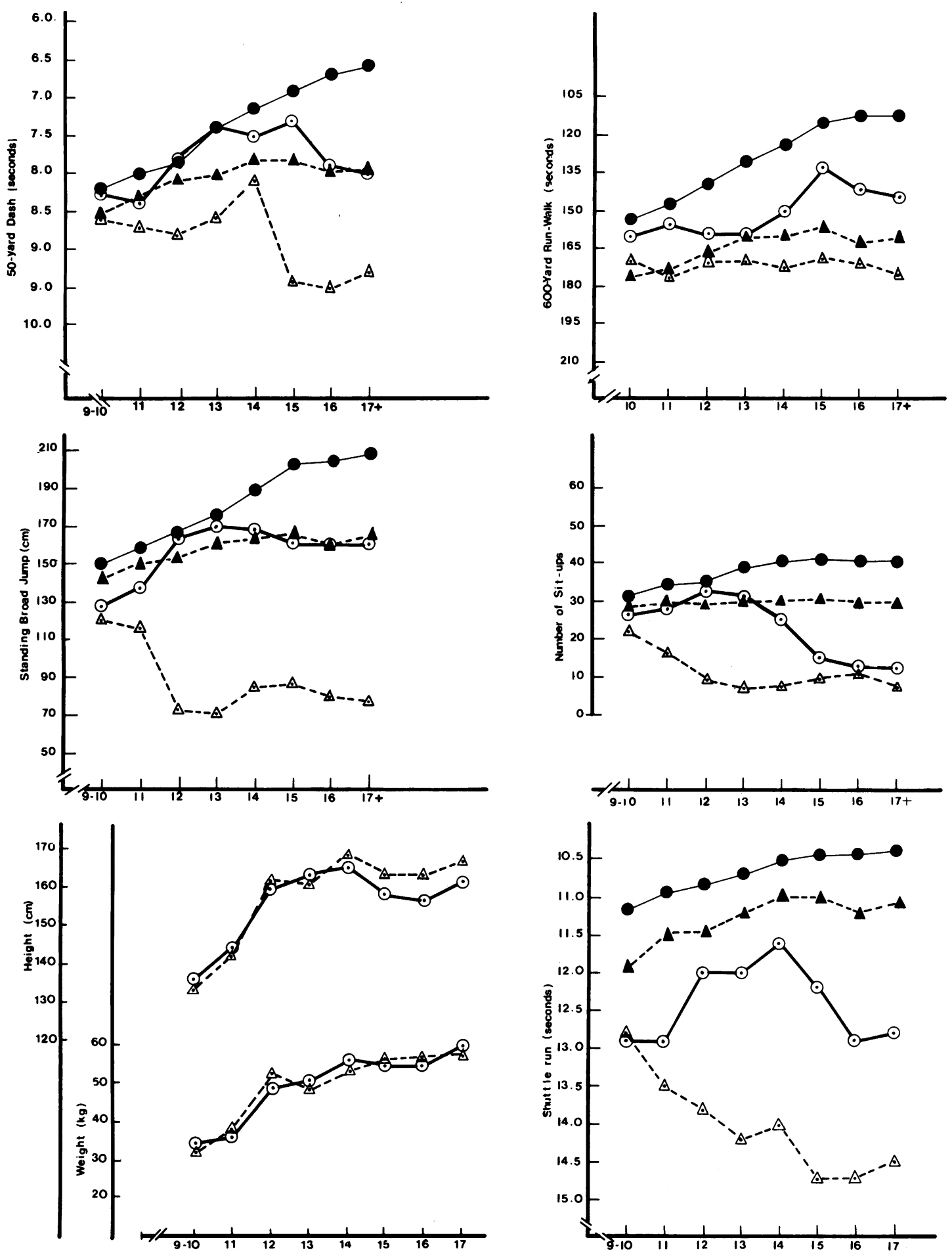

Fig. 1: Comparison of Egyptian fitness scores with AAHPER norms for males and females.

- Egyptian males $\triangle$ Egyptian females $\quad$ AAHPER male 50th percentile $\triangle$ AAHPER female 50th percentile 


\section{TABLE I}

Sample subdivisions and physical characteristics.

\begin{tabular}{|c|c|c|c|c|c|c|}
\hline \multirow[t]{2}{*}{ Level \& Age } & \multicolumn{3}{|c|}{ Males } & \multicolumn{3}{|c|}{ Females } \\
\hline & $n$ & $\begin{array}{c}\mathrm{Ht} \\
(\mathrm{cm})\end{array}$ & $\begin{array}{l}W t \\
(\mathrm{~kg})\end{array}$ & $\mathbf{n}$ & $\underset{(\mathrm{cm})}{\mathrm{Ht}}$ & $\begin{array}{c}W t \\
(\mathrm{~kg})\end{array}$ \\
\hline \multicolumn{7}{|c|}{$\begin{array}{l}\text { Upper Elementary } \\
\text { Schools }(4)^{*}\end{array}$} \\
\hline $9-10 y r$ & 74 & $\begin{array}{r}135.9 \\
\pm \quad 8.3\end{array}$ & $\begin{array}{r}34.1 \\
\pm \quad 5.7\end{array}$ & 81 & $\begin{array}{r}131.6 \\
\pm \quad 9.7\end{array}$ & $\begin{array}{r}32.4 \\
\pm \quad 5.2\end{array}$ \\
\hline $11 \mathrm{yr}$ & 34 & $\begin{array}{r}144.0 \\
\pm \quad 10.7\end{array}$ & $\begin{array}{r}36.9 \\
\pm \quad 8.8\end{array}$ & 22 & $\begin{array}{r}143.6 \\
\pm \quad 10.9\end{array}$ & $\begin{array}{r}37.1 \\
\pm \quad 7.3\end{array}$ \\
\hline \multicolumn{7}{|l|}{$\begin{array}{l}\text { Junior High } \\
\text { Schools (4)* }\end{array}$} \\
\hline $12 \mathrm{yr}$ & 39 & $\begin{array}{r}159.5 \\
\pm \quad 4.9\end{array}$ & $\begin{array}{r}48.9 \\
\pm \quad 4.5\end{array}$ & 21 & $\begin{array}{r}160.3 \\
\pm \quad 2.8\end{array}$ & $\begin{array}{r}50.3 \\
\pm \quad 1.4\end{array}$ \\
\hline $13 y r$ & 42 & $\begin{array}{r}162.2 \\
\pm \quad 5.5\end{array}$ & $\begin{array}{r}50.3 \\
\pm \quad 5.8\end{array}$ & 17 & $\begin{array}{r}160.5 \\
\pm \quad 2.1\end{array}$ & $\begin{array}{r}49.1 \\
\pm \quad 6.4\end{array}$ \\
\hline $14 \mathrm{yr}$ & 33 & $\begin{array}{r}164.9 \\
\pm \quad 5.3\end{array}$ & $\begin{array}{r}56.2 \\
\pm \quad 3.9\end{array}$ & 22 & $\begin{array}{r}167.2 \\
\pm \quad 3.4\end{array}$ & $\begin{array}{r}52.4 \\
+\quad 2.5\end{array}$ \\
\hline \multicolumn{7}{|l|}{$\begin{array}{l}\text { Senior High } \\
\text { Schools }(6)^{*}\end{array}$} \\
\hline $15 \mathrm{yr}$ & 43 & $\begin{array}{r}158.2 \\
\pm \quad 4.5\end{array}$ & $\begin{array}{r}55.7 \\
\pm \quad 4.7\end{array}$ & 54 & $\begin{array}{r}164.4 \\
\pm \quad 3.9\end{array}$ & $\begin{array}{r}55.5 \\
\pm \quad 3.6\end{array}$ \\
\hline $16 \mathrm{yr}$ & 44 & $\begin{array}{r}157.9 \\
\pm \quad 5.5\end{array}$ & $\begin{array}{r}55.5 \\
\pm \quad 5.5\end{array}$ & 42 & $\begin{array}{r}164.9 \\
\pm \quad 3.9\end{array}$ & $\begin{array}{r}56.7 \\
\pm \quad 3.6\end{array}$ \\
\hline $17 \mathrm{yr}$ & 90 & $\begin{array}{r}161.9 \\
\pm \quad 5.9\end{array}$ & $\begin{array}{r}59.4 \\
\pm \quad 5.3\end{array}$ & 52 & $\begin{array}{r}166.0 \\
\pm \quad 3.9\end{array}$ & $\begin{array}{r}57.3 \\
\pm \quad 3.0\end{array}$ \\
\hline
\end{tabular}

* Number in () indicates number of schools in grade classification

Following the initial tests, an intensified physical education programme was administered twice weekly for eight weeks. Activities such as basketball, soccer, running, and calisthenics were provided in a more vigorous fashion than done customarily including additional activities designed to emphasise agility, strength, and endurance. The same committee administered the post-training tests according to the pretraining schedule.

\section{RESULTS}

Median scores for each of eight age categories were compared to the AAHPER 50th percentile for each test. In general, the Egyptian scores were substantially below the median AAHPER score for each test item (Fig. 1). The only exceptions were pullups for males and flexedarm hang for females. Although up to age 14 Egyptian males had superior pullup scores they showed a dramatic decline over the age of 14. The superiority of Egyptian females in flexed-arm hang occurred in the 9 and 10 and 11-year-old groups but this dropped markedly below AAHPER median scores thereafter.

In general, the most dramatic differences between
Egyptian and AAHPER median scores occurred in the last three age classifications. Males averaged $24 \%$ below AAHPER median scores while females averaged $27 \%$ below. This observation may have resulted from the cross-sectional nature of the sampling technique since "reversals" in height and weight growth curves (Fig. 1) were also registered by these groups. The rather high dependence of AAHPER test scores on body composition could explain part of the differences observed in this study (Cureton, Boileau and Lohman, 1975).

To observe potential differences between the sexes, each item was treated statistically with an analysis of variance holding the effects of age, height and weight constant by covariance. These three factors were significant covariates in every item except shuttle run where height was not a significant covariate. Despite controlling the influence of age, height and weight, males averaged approximately $26 \%$ better performance ( $p<.01)$ than females on every comparable item (pullups and flexed-arm hand excluded).

To determine the effects of a twice weekly eightweek intensified physical education programme, unpaired t-tests were performed on pre- and post-training scores. Both sexes made significant improvements $(p<.001)$ on all tests. In males, the greatest improvements were made in pullups $(21 \%)$ and situps $(16 \%)$; the least improvements were made in shuttle run $(2 \%)$ and 50 -yd. sprint (3\%). In females, the greatest improvements were made in flexed-arm hang $(20 \%)$ and situps $(13 \%)$; the least improvements were made in shuttle run $(1 \%)$ and 50 -yd sprint $(1 \%)$. None of the improvements related significantly to age or initial fitness level.

\section{DISCUSSION}

These data are among the first large scale fitness reports on a third-world country. They are also the first nonAmerican AAHPER scores to be substantially below the American median on all items. This may reflect the trend in emerging nations or be unique to youth in Egypt; final judgment must await further testing.

The exact reasons why these scores were so low are difficult to pinpoint. One factor may be that despite the mechanisation, there has been little increase in the pursuit of vigorous, fitness-developing activities. Furthermore, there has been no large-scale promotion of fitness through the media, a fact which does not motivate the youth to exercise. Fortunately this was not an irreversible trend as shown by the significant improvements in all AHHPER items after only eight weeks of training.

It is very tempting to place a great deal of the blame for these low fitness scores on the lack of adequate nutrition among Egyptian youth. Substandard nutrition could seriously affect fitness scores; however, to date there has been no comprehensive nutritional survey of 
Egyptian children. Furthermore, schistosomiasis is still a serious problem among Egyptians (Lehman et al, 1973). The extent of the interaction of this parasitic infection and the nutritional status of these growing children is undocumented.
Perhaps the lower fitness scores for the girls above the age of 12 in this study may be attributed to the custom in many Islamic societies of withdrawing young women into domestic surroundings and away from vigorous participation in sports activities.

\section{REFERENCES}

AAHPER, 1976. AAHPER Youth Fitness Test Manual. Washington, DC.

Brunner, D. and Manelis, G., 1960 "Myocardial infarction among members of communal settlements in Israel". Lancet 2: 1049-50.

Campbell, W. R. and Pohndorf, R. H., 1961 "Physical fitness of British and United States children". In: Health and Fitness in the Modern World. Athletic Institute: Chicago, IL.

Costas, P., Garcia-Palmieri, M. R., Nazario, E. and Sorlia, P. D., 1978 "Relationship of lipids, weight, and physical activity to incidence of coronary heart disease: the Puerto Rico heart study". Am.J.Cardiol. 42: 653-8.

Cureton, K. J., Boileau, R. A. and Lohman, T. G., 1975 "A relationship between body composition measures and AAHPER test performances in young boys". Res.Quart.

Hunsicker, P. A., 1957 “AAHPER's youth fitness project". JOHPER 29: 24-6.

Knuttgen, H. G. 1961 “Comparison of fitness of Danish and American children". Res.Quart. 39: 809-11.

Krause, H. and Hirschland, R., 1954 "Minimum muscular fitness tests in school children". Res.Quart. 25: 178-88.

Lehman, J. S., Farid, Z., Smith, J. H., Bassily, S. and El-Masry, N. A., 1973 “Urinary schistosomiasis in Egypt: clinical, radiological, bacteriological, and parasitological correlations". Trans.R.Soc.Trop.Med.Hyg. 67: 384-99.

Norris, J. N., Heady, J. A., Raffle, P. A. B., Roberts, C. G. and Parks, J. W., 1953 “Coronary heart disease and physical activity of work". Lancet 2: 1053-57.

Sloan, A. W., 1966 "Physical fitness of South Africans compared with British and American high school children". So. African Med.J. 40: 688-90.

\section{BOOK REVIEW}

Title: AN INTRODUCTION TO MECHANICS OF HUMAN MOVEMENT

Author: J. Watkins

Publisher: MTP Press, Lancaster, 1983

Price: $£ 9.95 \quad 146$ pages

This is a neat little book of some 146 pages almost equally divided, following a three page introduction, into two sections dealing with linear and angular motion respectively. The Index is tiny, i.e. only about five or six entries per alphabetical step, and the only Appendix is not very informative. The illustrations are black and white line diagrams. The general lay-out has much in common with any elementary text in physics, as a glance at the list of contents will confirm, but this should not be allowed to deter the reader for a range of applications to sporting activity illustrating the principles presented. The style throughout is efficient and readable, the material presented is progressive and simple, and the pace of development slow enough to encourage the less numerate to persevere and achieve useful insights into the mechanical principles covered. First year physical education students without a strong science background will appreciate its publication. 